\section{BRAZIULIAN JOURNAL}

OF MEDICAL AND BIOLOGICAL RESHARCH

www.bjournal.com.br
ISSN 0100-879X

Volume 43 (02) 124-225 February 2010

BIOMEDICAL SCIENCES

AND

CLINICAL INVESTIGATION

Braz J Med Biol Res, February 2010, Volume 43(2) 124-126

Ethical research as the target of animal extremism: an international problem

P. Michael Conn and F.T. Rantin

The Brazilian Journal of Medical and Biological Research is partially financed by
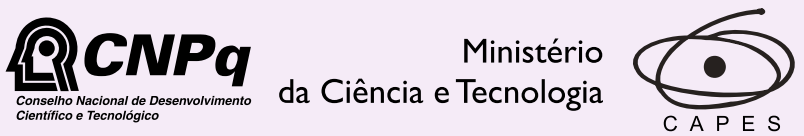

Ministério da Educação

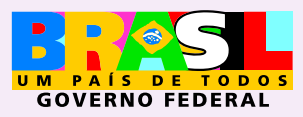

Institutional Sponsors 


\title{
Ethical research as the target of animal extremism: an international problem
}

\author{
P. Michael Conn ${ }^{1,2,3}$ and F.T. Rantin 4 \\ ${ }^{1}$ Office of Research Advocacy, Oregon Health and Science University, Beaverton, OR, USA \\ 2Divisions of Reproductive Sciences and Neuroscience, Oregon National Primate Research Center, \\ Beaverton, OR, USA \\ ${ }^{3}$ Departments of Pharmacology and Physiology, Cell and Developmental Biology, \\ and Obstetrics and Gynecology, Oregon Health and Science University, Beaverton, OR, USA \\ ${ }^{4}$ Departamento de Ciências Fisiológicas, Universidade Federal de São Carlos, São Carlos, SP, Brasil
}

\begin{abstract}
Animal extremism has been increasing worldwide; frequently researchers are the targets of actions by groups with extreme animal rights agendas. Sometimes this targeting is violent and may involve assaults on family members or destruction of property. In this article, we summarize recent events and suggest steps that researchers can take to educate the public on the value of animal research both for people and animals.
\end{abstract}

\section{Introduction}

First the UK, then the USA and now most of the world is engaged in what is sometimes called a "debate" about the value of animal research - and whether it should continue at all. Many characteristics of this debate suggest that the relationship between animal researchers and extremists is more accurately described as a war, since the interaction features casualties, spies and propaganda. Even more than in most wars, George Orwell's observation applies: "the first casualty in war is the truth".

\section{An international problem}

Ask your colleagues in the UK or USA about what it is like to have intruders break into their labs and pour acid on their data or "liberate" their animals. Ask scientists at the world's largest pharmaceutical companies about telephone threats and "home visits" - that is when an activist follows you home and threatens or intimidates you and your family there. Learn about e-mail "denial of service" or virus attacks, or envelopes armed with razor blades sent through regular mail. Talk to the researchers who get anonymous messages calling them "vivisectors" or who find pictures of their children and their home addresses posted on the Internet. Yes, it is more than just a war of words - and we researchers are on the frontlines.

In 1987, Tim Daley of the Animal Liberation Front (ALF) made it very clear: "In a war you have to take up arms and people will get killed, and I can support that kind of action by gasoline bombing". Consistent with that statement, and despite claims that they will never harm humans or animals, violence seems to be an increasing common tactic of extremist groups. In October 2009, for example, during the XI Brazilian Congress on Laboratory Animal Science, organized by the Brazilian Society of Laboratory Animal Science (SBCAL - formerly Brazilian College of Animal Experimentation - COBEA) in São Paulo, two companies manufacturing equipment for animal facilities and products for animal experimentation had their walls covered with graffiti containing the initials "ALF" and "COBEA". On the same day, plastic bottles filled with gasoline, simulating Molotov cocktails, were found inside of their areas, in a clear warning "next time we will set fires". The bottles were also labeled with the abbreviation, "ALF".

\section{Another case in point}

Some of the attacks by extremists are truly horrific. Consider the situation of Novartis CEO Daniel Vasella. An August 4, 2009 Press Release from the North American Animal Liberation Front Press Office noted, in part, "Drug maker Novartis AG said Tuesday that animal rights activists have stolen the (cremated) ashes of its CEO Daniel

Correspondence: F.T. Rantin, Departamento de Ciências Fisiológicas, UFSCar, Via Washington Luiz, km 235, 13565-905

São Carlos, SP, Brasil. E-mail: ftrantin@power.ufscar.br

Received September 12, 2009. Accepted January 7, 2010. Available online January 22, 2010. Published February 1, 2010. 
Vasella's mother and set fire to his Austrian hunting lodge". The message "Drop HLS Now" was spray-painted on the gravestone. The initials "HLS" refer to "Huntingdon Life Sciences", a company that has been targeted, along with their business partners (a practice known as "tertiary targeting") worldwide by animal extremists.

The press release continues to note that, "Graffiti slogans against Novartis and Vasella were also written on the church in Vasella's village of Risch in central Switzerland about 3 weeks ago, the company said. In May, the company's restaurant and sports facilities in France were damaged by fire".

The press release ends with a brief editorial observation, "We personally can only regret that Mr. Vasella was not present in the home when it burned".

While the severity of the action was extreme compared to other events worldwide, it is clear that researchers and research administrators are becoming targets of animal extremists. Our most important asset and defense is the public trust and understanding of the value that comes from animal research - both for people and animals. In recent months, extremists have made their opinions known in virtually every country where research involving animals is done. Even countries in which personal rights can be restrained, China and Russia, have been the target of animal extremism.

\section{How to combat extremism}

The real war is being fought over the understanding and support of the public. In the end, it is the public after all who will decide if animal research is to continue at all. They will do this by enacting legislation and making (or not making) appropriations for research. Accordingly, researchers must take the opportunity to address the untrue claims of extremists and remind the public that animals in research are protected by animal welfare laws and the products of animal research benefit both humans and animals. Every

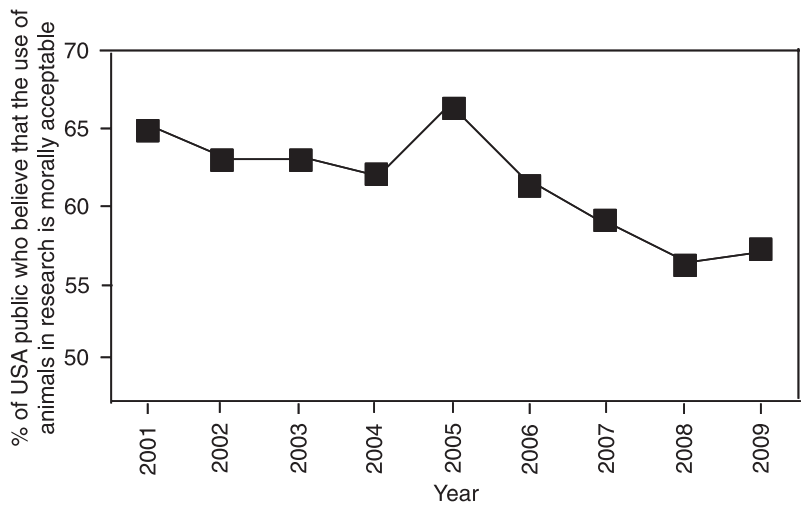

Figure 1 time there is a product that benefits humanity that comes from research, we must take the opportunity to tell the public. All too often the public fails to understand the link between basic research and drug development, believing that drugs come from drug companies and University researchers are working on unrelated matters.

The public must come to know that many of the images portrayed by animal extremists are of uncertain origin. Although they are portrayed being current, frequently they are not. By holding signs with images of animals, extremists induce the public to infer that they were taken recently inside the very building in which the protesters stand. Rarely is that true; in point of fact, very few of the protesters have even taken the opportunity to visit research facilities and see them first hand.

It is important to make the case that researchers are animal welfarists who understand that healthy animals are important in research and that it is our responsibility as human beings to care for our animals. We are the middle ground, with those who would afford rights to animals or those who would mistreat animals constituting the polar extremes.

It is important that researchers invite the public into their facilities so that the public can see, first-hand, the quality of the care and our commitment to it. We must interest young people in research and teach them its value and importance. Today's school children are tomorrow's voters and taxpayers.

Regrettably, we are not doing a very good job of this. Researchers are often poor at speaking to the public and few Universities provide incentives - salary or promotion for public outreach work.

The reduction of support for animal research in the USA (Figure 1) is typical of what is observed in many countries.

\section{What the public needs to know about animal research}

There are three "core" messages that we need to provide the public: 1) Animal research is closely regulated by the government. In that regard, Brazil made a major step forward when the National Congress passed the Law \#11,794, in October 2008 (available in http://www.mct.gov.br/index. php/content/view/308551.html). 2) Research is humane steps are taken to minimize pain and suffering, the smallest number of animals are used. We take steps to use animal alternatives (computers and cell cultures) whenever we can. If fish can be used for a particular experiment, we do not use mammals. Finally, 3) the result of animal research is valuable both to humans and to animals. It produces cures, new medicine and medical devices. Many medicines come directly from animal products: heparin used to prevent stroke comes from pig intestines and vaccines for $\mathrm{H} 1 \mathrm{~N} 1$ flu is made in eggs. 


\section{The law in Brazil}

According to the new Brazilian regulations, every research institution utilizing laboratory animals must be registered in the National Council of Control of Animal Experimentation - CONCEA. This council, part of the Ministry of Science and Technology, will be composed by members representing the main segments of the Brazilian scientific community. This includes the National Council for the Development of Science and Technology (CNPq), the Brazilian Academy of Science (ABC), the Brazilian Society for the Progress of Science (SBPC), the Federation of the Brazilian Societies of Experimental Biology (FeSBE), the Brazilian Society of Laboratory Animal Science (SBCAL), as well as the Ministries of Education; Science and Technology; Health and Agriculture. Also represented are the Brazilian Federation of Pharmaceutical Industries and two members representing the societies for the protection of animals. CONCEA will supervise the Committees of Ethics in Animal Utilization (CEUAs) present in every research institution, public or private, where laboratory animals are employed. CONCEA was designed to be a democratic and representative council where the animal experimentation can be regulated and decisions are taken. One hopes that the opportunities afforded by such a forum will obviate the need for violence by activists against animal researchers that has been observed in other countries.

In every country in which animal extremism has moved from peaceful demonstration to violence and destruction of property the key has been that scientists become willing to speak publicly about their work and its importance and not allow the public to accept the false images and erroneous claims. The public needs to understand that virtually every advance in health and nutrition has come from animal research. Unless we stand up for our profession and subscribe to the highest standards of animal care, we are easy targets for animal extremists.

\section{Further reading}

http://speakingofresearch.com - University students

http://www.amprogress.org/ - Americans for Medical Progress

http://www.nabr.org/ - National Association for Biomedical Research

Podcast for Neurology, The American Academy of Neurology. "Interview on the Animal Research War". http://www.aan.com/ rss/?event=feed\&channel=1 (September 22, 2009).

Conn PM, Parker JV. Terrorizing Medical Research. The Washington Post (syndicated by the LA Times- Washington Post) December 9, 2008 pg a19 op ed http://www.washingtonpost.com/wp-dyn/content/article/2008/12/07/AR2008120701925.html

Conn PM. Terrorism in the name of animal rights. The LA Times (syndicated by the LA Times-Washington Post). November 12, 2008 (http://www.latimes.com/news/printedition/opinion/la-oe-conn12-2008nov12,0,3327546.story).

Conn PM, Parker JV. Winners and Losers in the Animal Research War. American Scientist 96(3): 184-186 2008. http://www. americanscientist.org/issues/pub/winners-and-losers-in-the-animal-research-wars/

Conn PM, Parker JV. The Animal Research War. FASEB J 22 (5): 1294-1294, 2008. http://www.fasebj.org/cgi/content/full/22/5/1294

Conn PM. The War on Animal Research. The Scientist 22 (3): 40-46, 2008. http://www.the-scientist.com/article/display/54494/

Conn PM, Parker JV. Physiologists Embedded in the Animal Research. The Physiologist 51(3): 85-95 (non contiguous). 2008. http:// www.the-aps.org/publications/tphys/tphys6x08.pdf American Physiology Society

Conn PM, Parker JV. Letter to an Aspiring Scientist. ASCB News 31(5): 25, 2008. American Society for Cell Biology

Conn PM, Parker JV. Neurologists in the Cross-Hairs, World Neurology, April 2009

Conn PM, Parker JV. Awakening the American Public. RDS News (UK). January 2009. British Research Defense Society

Newsweek, December 10, 2009, http://www.newsweek.com/id/226336

Supplementary material http://www.bjournal.com.br/credits.htm 